\title{
Celioscopy and partial salpingectomy in a pregnant bitch
}

\author{
Fabíola Dalmolin $^{1^{*}}$ (D) Andriele da Costa Poerschke ${ }^{2}$ (i) Marília Teresa de Oliveira ${ }^{3}$ (i) \\ Saulo Tadeu Lemos Pinto Filho ${ }^{4}$ (i) João Pedro Scussel Feranti ${ }^{5}$ (i) Maurício Veloso Brun ${ }^{4}$ (i)
}

\author{
'Programa de Pós-graduação em Saúde, Bem-Estar e Produção Animal Sustentável da Fronteira Sul, Universidade Federal da Fronteira Sul \\ (UFFS), 85770-000, Realeza, PR, Brasil. E-mail: fabiola.dalmolin@uffs.edu.br. *Corresponding author. \\ ${ }^{2}$ Centro de Ensino Superior Riograndense (CESURG), Sarandi, RS, Brasil. \\ ${ }^{3}$ Universidade Federal do Pampa (UNIPAMPA), Uruguaiana, RS, Brasil. \\ ${ }^{4}$ Programa de Pós-graduação em Medicina Veterinária, Universidade Federal de Santa Maria (UFSM), Santa Maria, RS, Brasil. \\ ${ }^{5}$ Universidade da Região da Campanha (URCAMP), Alegrete, RS, Brasil.
}

ABSTRACT: This case report presents a celioscopy procedure followed by partial salpingectomy (PS) in a pregnant bitch referred to elective video assisted ovariohysterectomy. Through celioscopy it was visualized the embryonic vesicles and PS was performed after conversion to minioceliotomy. The puppies were born by eutocic delivery without clinical alterations. The case suggested that short and regular pneumoperitoneum is not deleterious to dog fetus and video surgery could be used in pregnant bitches. PS allows the fetus development and promotes bitch neutering.

Key words: embryonic vesicle, fetus development, neutering, ovariohisterectomy, uterine tube.

Celioscopia e salpingectomia parcial em fêmea canina gestante

RESUMO: Este trabalho relata um caso de celioscopia seguido de salpingectomia parcial (SP) em fêmea canina gestante encaminhada à ovariohisterectomia eletiva videoassistida. Por celioscopia foram identificadas vesículas gestacionais e a SP foi aplicada após conversão para miniceliotomia. Não foram observadas alterações clínicas nos filhotes, os quais nasceram por parto eutócico. Sugere-se que o pneumoperitônio regular por tempo reduzido não seja deletério para fetos caninos e a videocirurgia pode ser aplicada em caninos gestantes. A SP permite a continuidade do desenvolvimento fetal e a esterilização de fêmeas caninas.

Palavras-chave: vesícula embrionária, desenvolvimento fetal, castração, ováriohisterectomia, tuba uterina.

Elective bitch sterilization is beneficial because it counteracts overpopulation. The ovariohisterectomy (OHE) is a neutering surgery in that ovaries, uterine tubes and uterus are removed. In some countries, it is the most frequent surgery indicated to prevent estrus, to treat or prevent reproductive diseases, among others indications (FRANSSON, 2018). The partial salpingectomy (PS) refers to partially uterine tube removing and it is recommended due to ethic reasons once pregnancy is identified during surgery (SILVA et al., 2012).

OHE techniques are performed using midline, flank or laparoscopic accesses and stapling, ultrasonic scalpel, vessel-sealing devices or ligatures to hemostasis (FRANSSON, 2018). Among the usual techniques, the laparoscopic-assisted one are gaining popularity in veterinary, and the videoassisted two portals and bipolar coagulation is well described in dogs (DEVITT et al., 2005). When laparoscopic is compared to open surgery, the first promotes advantages such as less postoperative pain, fast recovering, minimal wound inflammation, fewer wound infection and superior visualization (DEVITT et al., 2005; FRANSSON, 2018).

In humans, laparoscopic is being performed in pregnant with increasing frequency, because it minimizes fetal risk without comprising the mother safety (JONATHAN et al., 2017). Although, laparoscopic ovariectomy in late gestation was related with no objective to maintain fetus (DONGAONKAR 
et al., 2019), video surgery data in pregnant bitches is sparse. On this way, the objective of this report is to describe a pregnant bitch submitted to celioscopy and neutered using PS by miniceliotomy, maintaining the fetus development.

A one-year-old mixed breed healthy bitch, weighting $9.2 \mathrm{~kg}$ was forwarded to elective $\mathrm{OHE}$ as a part of a study. After no alteration in clinical and laboratory examination, the patient was hospitalized $48 \mathrm{~h}$ before the surgery. The tutor mentioned that the animal did not presented estrous signs on the latest three months. It received orally nitenpyram (1 mg. $\left.\mathrm{kg}^{-1}\right)$, water and commercial food ad libitum, and remained on acclimatized environment $\left(22^{\circ} \mathrm{C}\right)$.

After $12 \mathrm{~h}$ fasting for food and $8 \mathrm{~h}$ for water, the abdomen was shaved and applied acepromazine $^{1}\left(0.05 \mathrm{mg} . \mathrm{kg}^{-1} \mathrm{IM}\right)$ and Ringer's lactate by venous access $\left(10 \mathrm{~mL} . \mathrm{kg} \cdot \mathrm{h}^{-1} \mathrm{IV}\right)$. The anesthetic induction used propofol ${ }^{2}$ (4 mg. $\mathrm{kg}^{-1} \mathrm{IV}$ ) and to the anesthetic maintenance, isoflurane was vaporized in $100 \%$ oxygen and adjusted to keep the adequate anesthetic plane (palpebral reflexes absent, corneal reflex present, and rotated eyeball), in spontaneous breathing system. Manual ventilation was performed if the end-tidal carbon dioxide raises $45 \mathrm{mmHg}$. It was applied a loading fentanyl dose $\left(1.25 \mu \mathrm{g} . \mathrm{kg}^{-1} \mathrm{IV}\right)$ followed by a constant rate infusion $\left(15 \mu \mathrm{g} . \mathrm{kg} \cdot \mathrm{h}^{-1} \mathrm{IV}\right)$ and sodium ampicillin dose (20 mg.kg- $\left.{ }^{1} \mathrm{IV}\right)$.

The patient was positioned in dorsal recumbence and an 11-mm trocar was applied by the Hasson-modified technique in the umbilicus. The pneumoperitoneum was instituted with $\mathrm{CO}_{2}$ at $1.5 \mathrm{~L} /$ min and $12 \mathrm{mmHg}$ (Figure 1A). During the routine abdominal inspection, before the second $11-\mathrm{mm}$ trocar insertion, it was observed the uterus enlarged and four embryonic vesicles (Figure 1B and 1C). The insufflation was interrupted after seven minutes and the umbilical incision was extended by approximately two centimeters caudally. The left uterine tube was exposed, dissected and two Halsted hemostats applied one centimeter apart. The segment between the clamps were excised and the extremities obliterated with polyglactin $9102-0$. The procedure was repeated in the right tube. The muscular abdominal closure was realized in cruciate isolate pattern, as well as the subcutaneous using the same threat. To dermorraphy

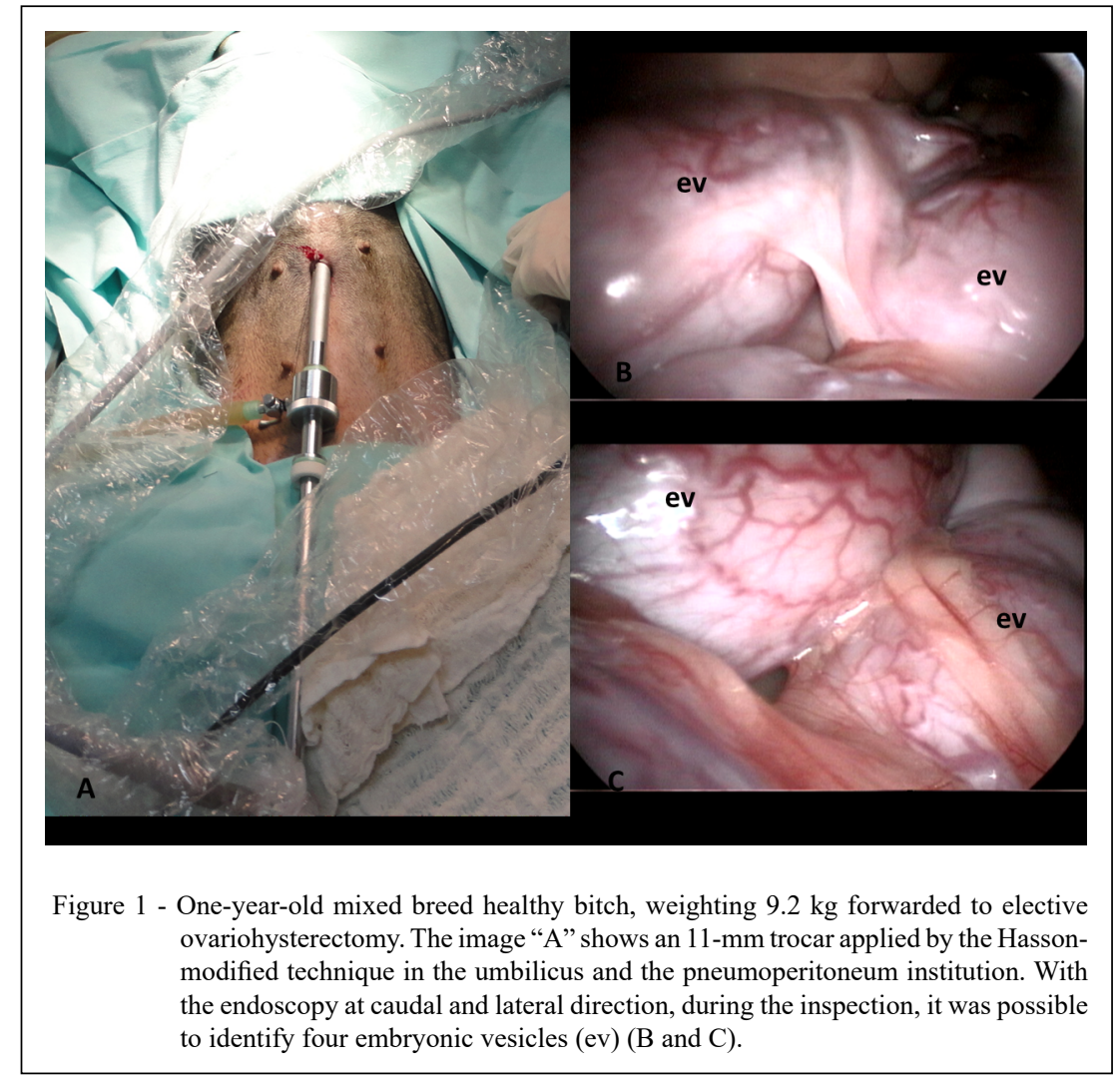

Ciência Rural, v.51, n.9, 2021. 
was applied the horizontal isolated mattress and nylon 3-0. The overall surgical time was $27 \mathrm{~min}$, the anesthetic procedure spent $37 \mathrm{~min}$ and $2.2 \mathrm{~L}_{\text {of }} \mathrm{CO}_{2}$ were used.

To the analgesia was applied a combined dipyrone and scopolamine formulation ${ }^{3}\left(25 \mathrm{mg} \cdot \mathrm{kg}^{-1}\right.$ and $0.2 \mathrm{mg} . \mathrm{kg}^{-1}$, IV, QID, $48 \mathrm{hr}$ ), followed by subsequent SC. The patient remained hospitalized and it was evaluated by clinical examination and ultrasound 24 hours after the surgery and after seven days. No clinical changes were detected in the bitch and fetus distress signals were not observed. The patient was discharged after $48 \mathrm{~h}$ and after seven days it was evaluated. No clinical alteration was detected and the skin sutures were removed. The delivery happened approximately 40 days after surgery and four healthy puppies were born. Bitch and puppies were evaluated 80 days after surgery and no alteration was detected. Since the birth until the evaluation, the puppies presented normal behavior and development.

Several neutering techniques are already described in bitches. The OHE is one of the most applied because promotes advantages such as ovarian and mammary disease prevention (FRANSON, 2018). Although, when pregnancy is recognized during a surgery, due to ethical reasons the OHE is contraindicated and the PS is an option (SILVA et al., 2012), as occur in this case. The case evolution was considered positive, because no alteration in the number of puppies or abnormalities was observed. On the same way, a study report smaller reabsorption number, describing 51 vesicles and 49 live fetuses delivered (SILVA et al., 2012).

However, despite the recognition that laparoendoscopic single site were viable to tubal occlusion in bitches (FERREIRA et al., 2013), as well as three-portal in triangulation (BRUN, 2015), we opted for miniceliotomy and verified that this access allows PS with small trauma compared to the conventional access. Another good possibility in this case was to put another 5-mm portal (3thr) between the others and do the surgery (BRUN, 2015) with portals "in line". Nowadays, with the gain of experience of our team and the results of this case, probably we will choose the PS by laparoscopic.

Over two decades ago laparoscopy was contraindicated in woman pregnancy by concerns for uterine injury from trocar placement and fetal perfusion due to pneumoperitoneum. As surgeons gained experience, the technique has become preferred for many surgical diseases in pregnant (JONATHAN et al., 2017). The most common non-obstetrical surgery to woman during pregnancy are acute appendicitis, cholecystitis, ovarian cysts, masses, torsions, splenic disorders, symptomatic hernias, etc. (JONATHAN et al, 2017). Surgery in pregnant dogs is not a routine, but it is a possible demand.

Considering the diagnostic tools, the image studies are preferred over laparoscopy, but when the last one is unavailable or inconclusive, laparoscopy may be considered and used judiciously. This precaution is because it may be an increased risk of preterm labor and fetal demise after unnecessary laparoscopy, as described in human appendicitis (JONATHAN et al, 2017). The recommendation for non-emergent procedures has been to avoid it at first and third trimesters to minimize abortion and preterm labor, respectively (JONATHAN et al, 2017). The patient of this case report was approximately three weeks gestation, what corresponds to the second trimester indicated to woman.

No complication as advanced delivery or fetal death happened in this case report. We believed that the pneumoperitoneum used were satisfactory, because increased distention (over $15 \mathrm{mmHg}$ ) can elevate the complication risk in healthy animals (FRANSSON, 2018) and it should be avoided in pregnant. Conversely a study presented no anesthetic complication in pregnant dogs using $12 \quad-15$ $\mathrm{mmHg}$, but the positioning adopted was the reverse Trendelenburg (DONGAONKAR et al., 2019). It must be considered that the pregnant diaphragm is upwardly displaced by the growing fetus, which results in decreased residual lung volume and functional residual capacity. For this, intra-abdominal pressure under $12 \mathrm{mmHg}$ is recommended, since over $15 \mathrm{mmHg}$ can induce hypercarbia and fetal acidosis (JONATHAN et al., 2017). The pregnant dog of this case received insufflation as recommended to woman (JONATHAN et al., 2017) and to no pregnant dogs (DEVITT et al., 2005).

When pregnant human is in supine position, the gravid uterus pressure the inferior cava resulting in decreased venous return, reduction in cardiac output, maternal hypotension and decreased placental perfusion (JONATHAN et al., 2017). The observation is similar to cesarean dogs, in which dorsal recumbence should be avoided and the table tilted 10-15 degrees to the side or cranially elevated are performed to minimize pressure on cava vein or diaphragm, respectively. Dongaonkar et al. (2019) described that pregnant bitch patient positioned in laterally oblique recumbency and reverse Trendelemburg provided the optimal operating space. In this case report the dorsal recumbence was used and no complications were observed, probably due to relatively small uterus size. 
The fetal acidosis associated to fetal instability in $15 \mathrm{mmHg} \mathrm{CO}_{2}$ pneumoperitoneum have been documented in ewe. Intra-amniotic pressure increases significantly at insufflation but no significant changes happened in maternal hemodynamic, fetal variables or uterine blood flow, as well as no fetal death or preterm labor. It was observed in one hour insufflation a marked increase in PaCO2-to-end-tidal gradient and capnography was considered an inadequate guide to the ventilation (CRUZ et al., 1996). In the case of the pregnant dog, it was used and no complication was observed, although it couldn't be proved.

On this way, intraoperative fetal heart rate monitoring was described as the most accurate method to detect fetal distress during laparoscopy (JONATHAN et al, 2017). In veterinary it is considered difficult, considering the number of amniotic vesicles to monitorate; although, Doppler ultrasound could be an option. In this case, the pregnancy time was estimated in three weeks, and it is considered a limiting factor because is the moment in that the heart rate was not still detectable (BURK \& FEENEY, 2003).

Safe abdominal access for laparoscopy can be accomplished using open or closed technique, if applied appropriately. The concern for the use of closed access, as Veress needle or optical entry, is that it has been largely based on the potentially high risk of injury (JONATHAN et al., 2017). In this case, the open technique was applied carefully. So, iatrogenic trauma to the pregnant uterus and other organs is unlikely (BRUN, 2015).

PS could be indicated in the second trimester dog pregnancy in order to neuter bitches while permits gestation continuation without expectation to prevent other diseases. Adequate pneumoperitoneum (12 $\mathrm{mmHg}$ ) for short time $(7 \mathrm{~min})$ appears not to be deleterious to fetus development. The overall observed results open fields to future researches with adequate number of patients to establish the safety of pneumoperitoneum on dog fetuses.

\section{ACKNOWLEDGEMENTS}

This work was supported by Conselho Nacional de Desenvolvimento Científico e Tecnológico $(\mathrm{CNPq})$, and it was financed in part by the Coordenação de Aperfeiçoamento de Pessoal de Nível Superior (CAPES). Brasil - Finance code 001.

\section{BIOETHICS AND BIOSSECURITY COMMITTEE APPROVAL}

The animal was selected to a study part approved by the Comitê de Ética no Uso de Animais (081/2012), according to Consellho Nacional de Controle de Experimentação Animal (CONCEA).

\section{DECLARATION OF CONFLICT OF INTEREST}

The authors declare no conflict of interest. The founding sponsors had no role in the design of the study, in the collection, analyses, or interpretation of data; in the writing of the manuscript, and in the decision to publish the results.

\section{AUTHORS' CONTRIBUTIONS}

All authors contributed equally for the conception and writing of the manuscript.

\section{REFERENCES}

BRUN, M. V. Cirurgias do aparelho reprodutor feminino de caninos. In: BRUN, M. V. Videocirurgia em Pequenos Animais. Rio de Janeiro: Roca, 2015. Chap. 14. p. 186-213.

BURK, R. L.; FEENEY, D. A. The abdomen. In: Small Animal Radiology and Ultrasonography. 2.ed. Missouri : Saunders, 2003. Chap. 3. p.249-476.

CRUZ, A. M. et al. Intraabdominal carbon dioxide insufflation in the pregnant ewe. Uterine blood flow, intraamniotic pressure, and cardiopulmonary effects. Anesthesiology, 1996, v.85, p.1395-402. Available from: <https://pubmed.ncbi.nlm.nih.gov/8968187/>. Accessed: Mar. 18, 2020. doi: 10.1097/00000542-199612000-00021.

DEVITT, C. M. et al. Duration, complications, stress, and pain of open ovariohysterectomy versus a simple method of laparoscopicassisted ovariohysterectomy in dogs. Journal of the American Veterinary Medical Association, 2005, v.227, n.6, p.921-927. Available from: <https://pubmed.ncbi.nlm.nih.gov/16190590/>. Accessed: Mar. 18, 2020. doi: 10.2460/javma.2005.227.921.

DONGAONKAR, K. R. et al. Laparoscopic ovariectomy in dogs in late gestation. BMC Veterinary Research, 2019, v.15, n.19, p.1-6. Available from: <https://bmcvetres.biomedcentral.com/ articles/10.1186/s12917-018-1770-z>. Accessed: Jun. 01, 2020. doi: 10.1186/s12917-018-1770-z.

FERREIRA, G. S. et al. 2013. Tubal occlusion in dogs using the technique laparo-endoscopic single site surgery (LESS) and videoassisted technique. Revista Brasileira de Medicina Veterinária, 2013, v.35(1), p.49-54. Available from: <http://rbmv.org/index. php/BJVM/article/view/652/512>. Accessed: May, 18, 2020.

FRANSSON, B. A. Ovaries and uterus. In: TOBIAS, K. M.; JOHNSTON, S. A. Veterinary Surgery: Small Animal. Saint Louis : Elsevier Saunders, 2018. Chap. 109. p.2109- 2129.

JONATHAN, P. P. et al. Guidelines for the use of laparoscopy during pregnancy. Society of American Gastrointestinal and Endoscopic Surgeons (SAGES). 2017. Available from: $<$ https://www. sages.org/publications/guidelines/guidelines-for-diagnosis-treatmentand-use-of-laparoscopy-for-surgical-problems-during-pregnancy/>. Accessed: May, 18, 2020. doi: 10.1007/s00464-017-5637-3.

SILVA, A. C. et al. Sterilization in queens by partial salpingectomy (including pregnant) versus ovariohysterectomy. Ciência Rural. v.42, p.507-513, 2012. Available from: <http://www.scielo.br/ scielo.php?pid $=$ S0103-84782012000300020\&script $=$ sci abstract $>$. Accessed: Mar. 18, 2019. doi: 10.1590/S0103-84782012000300020. 